New Drug Update

\title{
Linaclotide: a guanylate cyclase agonist for treatment of irritable bowel syndrome with constipation and chronic constipation in adults
}

\author{
Deepika Tikoo*, Meenakshi Gupta
}

Department of Pharmacology, Sri Guru Ram Das Institute of Medical Sciences \& Research, Amritsar 143001, Punjab, India

Received: 7 February 2013

Accepted: 11 February 2013

*Correspondence to:

Dr. Deepika Tikoo,

Email: dtikoo@gmail.com

(C) 2013 Tikoo D et al. This is an open-access article distributed under the terms of the Creative Commons Attribution License, which permits unrestricted use, distribution, and reproduction in any medium, provided the original work is properly cited.

\begin{abstract}
Linaclotide, a 14 aminoacid peptide is an intestinal secretagogue and works by stimulating guanylate cyclase (GC-C) present in the intestinal epithelium, which leads to improvement in symptoms of irritable bowel syndrome with constipation and chronic constipation in adults. Treatments available currently for these gastrointestinal problems have not been very satisfactory and many new options are therefore being explored to provide relief to these patients. Linaclotide has shown promising results in various clinical trials and hence was approved by US Food and Drug Administration (FDA) in 2012.
\end{abstract}

Keywords: Linaclotide, Irritable bowel syndrome, Chronic constipation, Guanylate cyclase

\section{INTRODUCTION}

Irritable bowel syndrome (IBS) is a functional bowel disorder characterized by chronic abdominal pain/discomfort and altered bowel habits in the absence of an organic cause. ${ }^{1,2}$ It affects all ages and shows a female predominance. The diagnosis of IBS is made if there is recurrent abdominal pain for at least 3 days per month in the last 3 months along with two or more of the following: pain is improved with defecation and/or its onset is associated with a change in stool frequency and / or its onset is associated with a change in appearance of stool. ${ }^{1}$ The altered bowel habits can vary from diarrhea, constipation, constipation alternating with diarrhea or normal bowel habits alternating with either diarrhea and/or constipation. In IBS patients with constipation (IBS-C), the constipation initially is episodic and gradually becomes continuous. ${ }^{1,2}$

Chronic constipation (CC) also known as functional constipation, according to Rome III criteria is characterized by the presence of two or more symptoms of constipation during at least $25 \%$ of defecations like straining, lumpy/ hard stools, sensation of incomplete evacuation, sensation of anorectal obstruction or blockade, manual maneuvers to facilitate evacuation, present for at least last 3 months and onset of symptoms six months prior to diagnosis. ${ }^{3}$ The diagnosis of $\mathrm{CC}$ can be made if there is insufficient criteria for IBS, loose stools are rarely present without the use of laxatives and there are less than three bowel movements per week. ${ }^{3}$

New drugs are being developed for the treatment of IBS$\mathrm{C}$ and $\mathrm{CC}$ as their current therapeutic regimen looks unsatisfactory and one such recent drug molecule made available in the market is linaclotide. It was approved by FDA on August 30, 2012 and was marketed in US on December 2012 under the trade name of Linzess. ${ }^{4}$

\section{LINACLOTIDE}

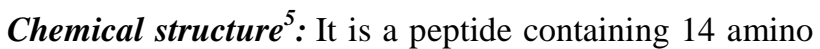
acids.

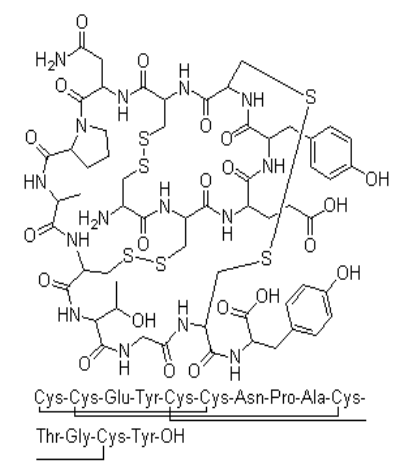




\section{MECHANISM OF ACTION}

Linaclotide is structurally related to endogenous guanylin peptide family of hormones which are responsible for maintaining fluid and electrolyte balance in the intestine. It stimulates guanylate cyclase $\mathrm{C}$ (GC-C), present abundantly in the intestinal epithelium, which is the principal receptor for heat stable enterotoxins (ST peptides) of Escherichia coli induced secretary diarrhea. Activation of GC-C stimulates the production of cyclic guanosine monophosphate (cGMP). It leads to induction of signaling pathway causing stimulation of chloride and bicarbonate secretion in the intestinal lumen through opening of cystic fibrosis transmembrane conductance regulator (CFTR) chloride channels. Linaclotide also inhibits sodium absorption from the lumen by blockade of sodium proton exchanger. Therefore there occurs an increase in frequency and ease of defecation. ${ }^{6-8}$

\section{CLINICAL STUDIES}

Phase I trial conducted on 48 subjects who were administered multiple ascending dose of linaclotide 30 , 100,300 or $1000 \mu \mathrm{g}$ once daily for seven days showed that linaclotide was well tolerated, with a statistical significant increase in stool frequency. ${ }^{2}$

Another efficacy \& safety study was conducted on 42 patients of chronic functional constipation, who were randomized to receive one of the three doses of linaclotide $(100,300$ or $1000 \mu \mathrm{g})$ or placebo once daily for 14 days. There was a dose dependent increase in frequency of weekly spontaneous bowel movements with $100 \mu \mathrm{g}$ dose group as compared to placebo (change 6.18 v/s 2.76 for placebo) and complete, spontaneous bowel movements (changes of 2.16, 2.90 and 3.19 with 100, 300 and $1000 \mu \mathrm{g}$ dose respectively as compared to 1.30 with placebo). Stool consistency and straining also improved in all dosing groups. Diarrhea was the most common side effect which occurred in $13 \%$ of all study patients and it did not show a dose dependent effect. ${ }^{2}$

In the first phase $2 \mathrm{a}$, randomized double blind placebo controlled trial of 36 patients with IBS-C , a daily five day course of linaclotide $100 \mu \mathrm{g}$ or $1000 \mu \mathrm{g}$ accelerated colon emptying in a dose dependent manner (with $1000 \mu \mathrm{g} ; \mathrm{P}=0.004)$. Also linaclotide shortened the time to first bowel movement $(p=0.037)$ and improved ease of stool passage $(p<0.001){ }^{2,6}$ In another phase $2 \mathrm{~b}$ trial in 420 patients with IBS-C, linaclotide was given in doses of $75,150,300$ or $600 \mu \mathrm{g}$ or placebo once daily for 12 weeks. There was increase in daily stool frequency with all doses more than placebo $(p<0.01)$, improvement in stool consistency and straining along with decrease in abdominal pain scores ( $p<0.001, p<0.05$ respectively) as compared to placebo. ${ }^{2}$

Two parallel, randomized, placebo controlled, double blind phase III trials on 1272 patients with chronic constipation were conducted in 2011. Patients were administered either placebo or linaclotide (145 $\mu \mathrm{g}$ or 290 $\mu \mathrm{g}$ ) once daily for 12 weeks. The first trial (trial 01) consisted of 630 patients while in the second trial (trial 303), there were 642 patients. The primary end point was $\geq 3$ complete spontaneous bowel movements (CSBMs) per week and an increase of at least one CSBM from baseline for at least 9 out of 12 weeks. There was early and sustained improvements in bowel symptoms and CSBMs in linaclotide groups in both the trials. In trial 01, $16.0 \%$ and $21.3 \%$ patients receiving $145 \mu \mathrm{g}$ dose and $290 \mu \mathrm{g}$ dose respectively showed an increase of at least one CSBM from baseline for $\geq 9$ of 12 weeks as compared to $6.0 \%$ in placebo group $(p=0.0012$ and $p<0.0001)$. While in trial 303, the improvement was seen in $21.2 \%(145 \mu \mathrm{g})$ and $19.4 \%(290 \mu \mathrm{g})$ patients as compared to placebo group $(3.3 \%)(p<0.0001)$.

Secondary end point like measurement of stool frequency, stool consistency, severity of straining, abdominal discomfort, bloating and constipation severity during the 12 week period were also assessed and it was seen that linaclotide treated patients showed significant improvements as compared to placebo in all these end points. Patients in both the trials on linaclotide showed an improvement in quality of life assessments as was seen with Patient Assessment of Constipation Quality of Life (PAC-QOL) scale scores.

The common adverse even reported was diarrhea $(16 \%$ with $145 \mu \mathrm{g}, 14.2 \%$ with $290 \mu \mathrm{g}$ versus $4.7 \%$ with placebo), flatulence $(5.6 \%, 5.0 \%$ versus 5.2 with placebo) and abdominal pain $(4.0 \%, 4.7 \%$ versus $3.1 \%$ with placebo). The patients who discontinued treatment due to adverse events were higher in linaclotide groups $(7.9 \%$ with $145 \mu \mathrm{g}, 7.3 \%$ with $290 \mu \mathrm{g}$ ) as compared to placebo $(4.2 \%)$ and it was mainly because of diarrhea. There was a single case of death during the trial due to an overdose of fentanyl and it was not thought to be related to linaclotide. ${ }^{2,3,9}$

The efficacy and safety of linaclotide was also evaluated in IBS-C in various phase III studies. One such double blind, placebo controlled study, randomized 800 patients to either receive oral linaclotide $290 \mu \mathrm{g}$ or placebo once daily for 12 weeks, followed by a 4 week randomized withdrawal period. The primary endpoint were (i) FDA end point, which was defined as a patient who met both the following criteria in the same week for at least 6 out of 12 weeks of treatment period: (a) an improvement of $\geq$ $30 \%$ from baseline in the average of the daily worst abdominal pain scores (b) an increase of $\geq$ CSBM from baseline; (ii) an improvement of $\geq 30 \%$ in abdominal pain for at least 9 of 12 weeks (iii) $\geq 3$ CSBMs and an increase of $\geq 1$ CSBM from baseline for at least 9 of 12 weeks (iv) combined end point which defines responder as a patient who met the criteria for both (ii) and (iii) in the same week. Secondary end points were a 12 week change from baseline in abdominal pain, abdominal discomfort, abdominal bloating, stool frequency, stool consistency and severity of straining. The FDA end point was met by 
$33.6 \%$ patients on linaclotide as compared to $21.0 \%$ patients in placebo group $(p<0.0001)$. Greater responders were seen in linaclotide group for the other three primary end points than placebo group $(34.3 \%$ with linaclotide $\mathrm{v} / \mathrm{s}$ $27.1 \%$ with placebo; $19.5 \% \mathrm{v} / \mathrm{s} 6.3 \%$ and $12.1 \% \mathrm{v} / \mathrm{s}$ $5.1 \%)(p<0.05)$. Statistical significant improvements in secondary end points were also observed in linaclotide group as compared to placebo $(p<0.001)$. During the 4 week randomized withdrawal period, patients who were re-randomized to placebo from linaclotide group showed the return of symptoms (increase in worst abdominal pain, decrease in CSBMs as was seen in placebo group). Patients who continued with linaclotide treatment showed sustained improvement in all symptoms while those who switched over from placebo to linaclotide group showed improvement in symptoms just like the linaclotide treated group. The most common adverse effects seen were diarrhea (19.5\% with linaclotide v/s 3.5 with placebo), abdominal pain $(5.4 \% \mathrm{v} / \mathrm{s} 2.5 \%)$ and flatulence $(4.9 \% \mathrm{v} / \mathrm{s}$ $1.5 \%)^{8}$

Another phase III study conducted on 804 patients of IBS-C was conducted and the patients either received linaclotide $290 \mu \mathrm{g}$ or placebo once daily for 26 weeks. The end points were similar to above study. In the linaclotide group, $33.7 \%$ patients were FDA end point responders vs. $13.9 \%$ of placebo-treated patients $(p<0.0001)$. The other primary end points and all secondary end points were also statistically significantly improved with linaclotide as compared to placebo. The incidence of adverse events was similar between both groups, except for diarrhea, which led to discontinuation of $4.5 \%$ patients on linaclotide and $0.2 \%$ of placebo patients. ${ }^{10}$

\section{DOSAGE AND ADMINISTRATION}

The recommended dose of linaclotide in patients with IBS-C and chronic constipation is $290 \mu \mathrm{g}$ and $145 \mu \mathrm{g}$ respectively taken orally once daily on an empty stomach at least 30 minutes before breakfast. ${ }^{11}$

\section{CONTRAINDICATIONS AND PRECAUTIONS}

Linaclotide, in animal studies on young juvenile mice (13 week old) caused death in them hence its use is contraindicated in children upto 6 years of age while it should be avoided in pediatric patients between 6-17 years of age as there is no clinical efficacy and safety data available for them. ${ }^{11}$

\section{PLACE IN THERAPY}

The results of clinical studies with linaclotide suggest that linaclotide by its unique mechanism of action is efficacious in treating symptoms of IBS-C and chronic constipation. Also its good safety profile makes it a promising therapeutic option for such patients.

\section{Funding: No funding sources \\ Competing interests: None declared \\ Ethical approval: Not required}

\section{REFERENCES}

1. Owyang C. Irritable Bowel Syndrome. In: Fauci AS, Braunwald E, Kasper DL, Hauser SL, Longo DL, Jameson JL, Localzo J, eds. Harrison's Principles of Internal Medicine. $17^{\text {th }}$ ed. New York, NY: McGraw-Hill; 2008:1899-903.

2. Lee N, Wald A. Linaclotide: evidence for its potential use in irritable bowel syndrome and chronic constipation. Core Evid 2012;7:39-47.

3. Lacy BE, Levenick JM, Crowell M. Chronic constipation: new diagnostic and treatment approaches. Ther Adv Gastroenterol 2012;5:233-47.

4. International Foundation for Functional Gastrointestinal Disorders. Linaclotide (Linzess). Available at http://www.aboutibs.org/site/newsevents/news/industry-news/linaclotide-linzess. Accessed 6 February 2013.

5. Chem blink. Linaclotide. Available at http://www.chemblink.com/products/851199-592.htm. Accessed 6 February 2013.

6. Bharucha AE, Linden DR. Linaclotide-A secretagogues and antihyperalgesic agent-what next? Neurogastroenterol Motil 2010;22:227-31.

7. Camilleri M, Bharucha AE. Behavioural and new pharmacological treatments for constipation: getting the balance right. Gut 2010;59:1288-96.

8. Rao S, Lembo AJ, Shiff SJ, Lavins BJ, Currie MG, Jia XD et al. A 12-Week, Randomized, Controlled Trial With a 4-Week Randomized Withdrawal Period to Evaluate the Efficacy and Safety of Linaclotide in Irritable Bowel Syndrome with constipation. Am J Gastroenterol 2012;107:1714-24.

9. Lembo AJ, Schneier HA, Shiff SJ, Kurtz CB, MacDougall JE, Jia XWD, et al. Two randomized trials of linaclotide for chronic constipation. N Engl J Med 2011;365:527-36.

10. Chey WD, Lembo AJ, Lavins BJ, Shiff SJ, Kurtz $\mathrm{CB}$, Currie MG, et al. Linaclotide for irritable bowel syndrome with constipation: a 26-week, randomized, double-blind, placebo-controlled trial to evaluate efficacy and safety. Am J Gastroenterol 2012;107:1072-12.

11. Goldenberg MM. Pharmaceutical Approval Update. P T 2012;37:620,622,649.

doi:10.5455/2319-2003.ijbcp20130323

Cite this article as: Tikoo D, Gupta M. Linaclotide: a guanylate cyclase agonist for treatment of irritable bowel syndrome with constipation and chronic constipation in adults. Int J Basic Clin Pharmacol $2013 ; 2: 224-6$. 